\title{
A SUBSTITUTE NAME FOR THE EXTINCT GENUS STENELYTRON KUKALOVÁ (PROTELYTROPTERA)
}

\author{
By Jarmila Kukalova-Peck \\ Department of Earth Sciences, Carleton University \\ Ottawa, Ontario, Canada K1S 5B6
}

In 1966 I described a new species of the extinct order Protelytroptera belonging to a new genus, Stenelytron, and representing a new family, Stenelytridae. Having recently learned from Professor F. M. Carpenter that the name Stenelytron is preoccupied, I am herein proposing a replacement name, as follows:

Labidelytron, nomen novum pro Stenelytron Kukalová, 1966, p. 102, non Handlirsch, 1906, p. 451. The type species, Stenelytron enervatum Kukalová, 1966, original designation, becomes Labidelytron enervatum (Kukalová), new combination. The genus is known only from the Permian of New South Wales, Australia.

The family name, Stenelytridae Kukalová, 1966, p. 102, is herein replaced by Labidelytridae. The genus Xenelytron (Kukalová), 1966, p. 105, also from the Permian of New South Wales, is the only other genus known in the family.

\section{Reference Cited}

\section{HANDliRsCh, ANTon}

1906. Die fossilen Insekten und die Phylogenie der rezenten Formen. P. 1-640, pl. 1-26. Engelmann (Leipzig).

1966. Protelytroptera from the Upper Permian of Australia, with a discussion of the Protocoleoptera and Paracoleoptera. Psyche 73: 89-111. 

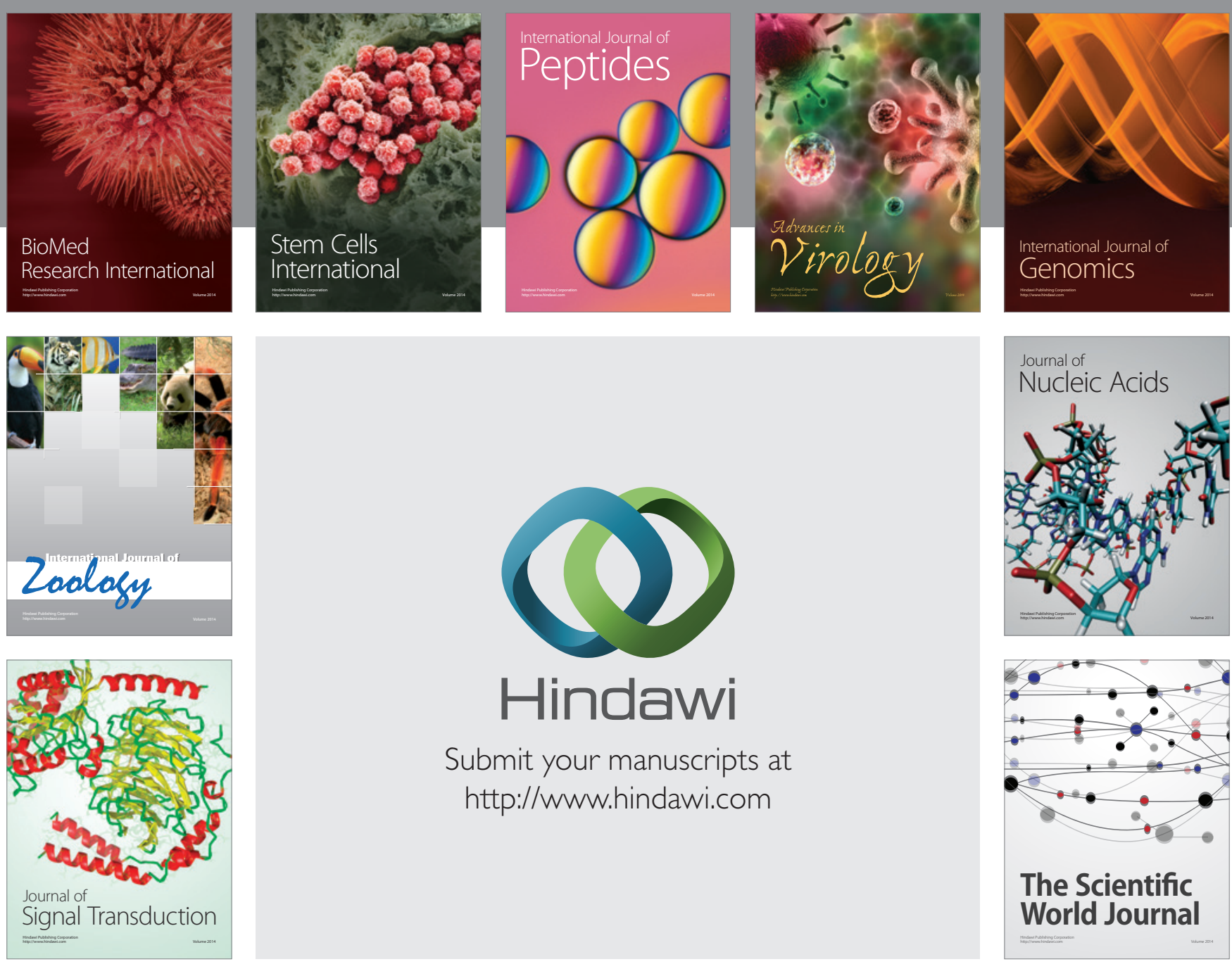

Submit your manuscripts at

http://www.hindawi.com
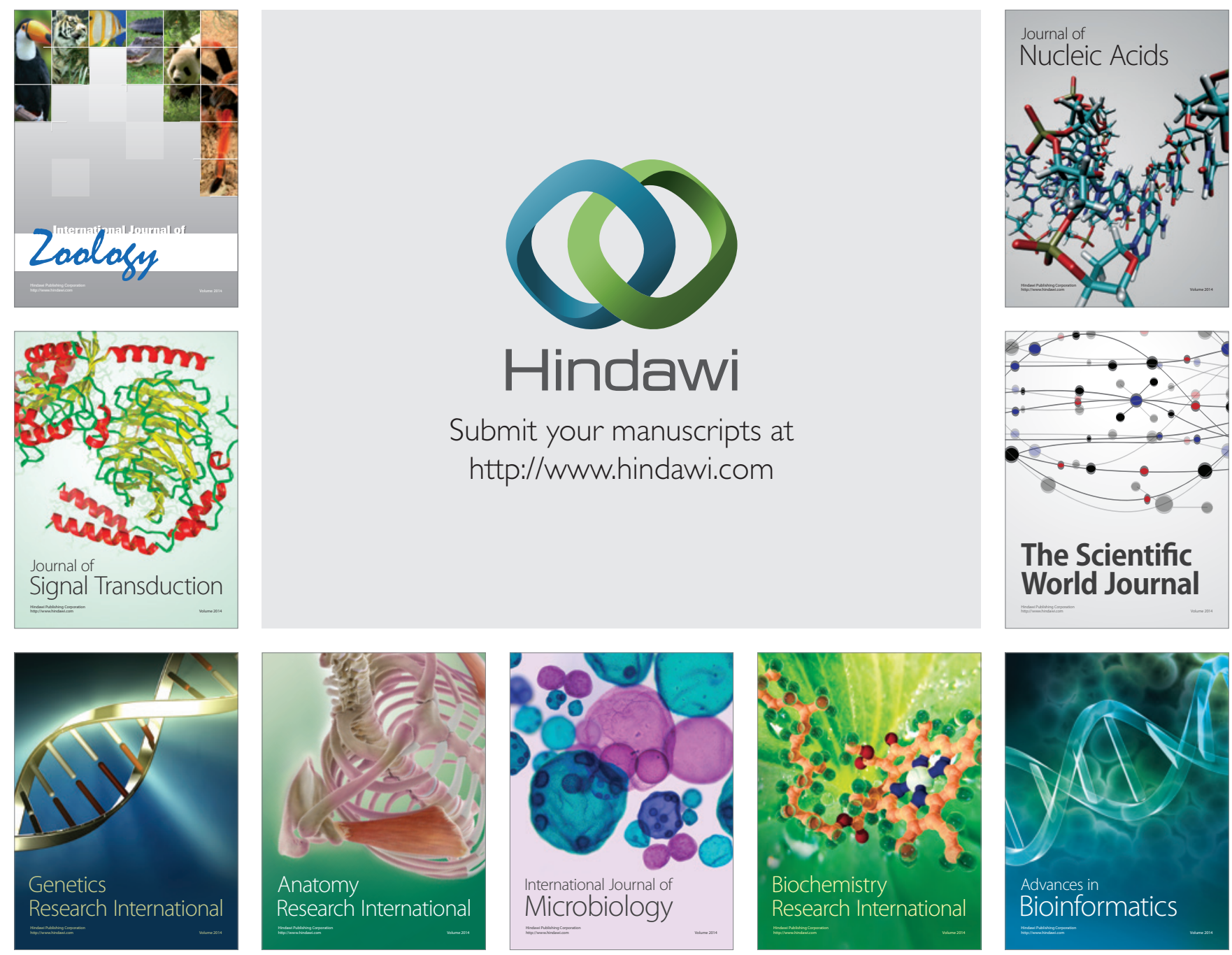

The Scientific World Journal
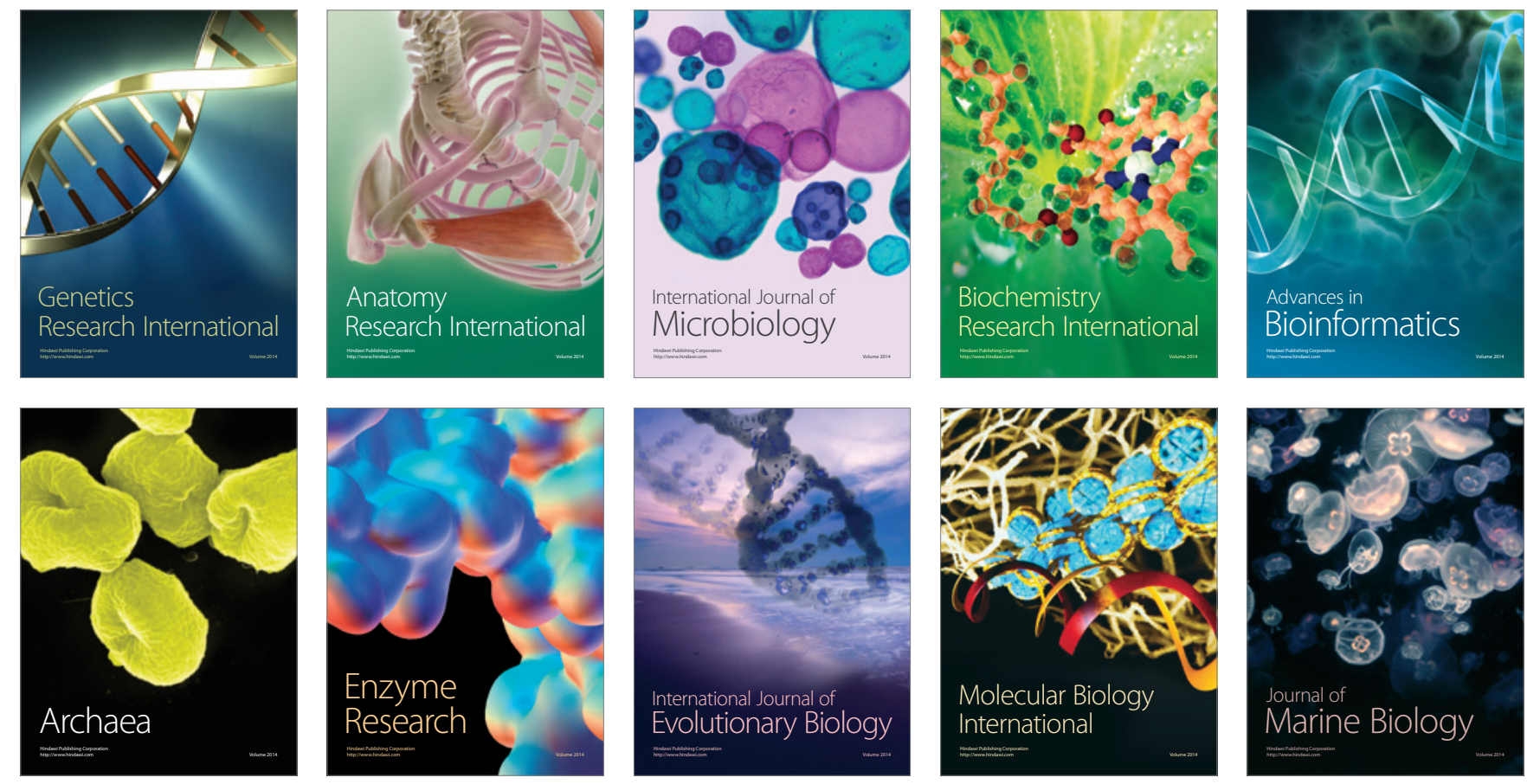